\title{
APLIKASI SISTEM PAKAR DIAGNOSIS GANGGUAN GIZI PADA ANAK MENGGUNAKAN METODE DEMPSTER SHAFER
}

\author{
${ }^{1}$ Ade Mubarok, ${ }^{2}$ Sari Susanti, ${ }^{3}$ Novi Imelia \\ ${ }^{1}$ Universitas Adhirajasa Reswara Sanjaya \\ ${ }^{1}$ e-mail: job.dosen@gmail.com \\ 2Universitas Adhirajasa Reswara Sanjaya \\ ²e-mail: sarisusanti@ars.ac.id \\ ${ }^{3}$ Universitas Adhirajasa Reswara Sanjaya \\ ${ }^{3}$ e-mail: novi.imelia2@gmail.com
}

\begin{abstract}
Abstrak
Gizi merupakan faktor penentu kualitas sumber daya manusia di masa mendatang, selain itu status gizi yang baik dan asupan makanan yang sehat seimbang mempunyai peranan penting dalam menentukan kesehatan dan kecerdasan seseorang. Usia anak prasekolah lebih beresiko mengalami gangguan gizi seperti gizi kurang dan gizi lebih akibatnya dapat menimbulkan penyakit. Kurangnya kepedulian terhadap gizi anak serta terbatasnya pengetahuan mengenai berbagai penyakit akibat gangguan gizi membuat orang tua kesulitan untuk mendiagnosis penyakit yang akan menyerang anak mereka. Maka dalam penelitian ini dibuatkan sebuah alat bantu berupa sistem pakar berbasis android untuk mendiagnosis penyakit akibat gangguan gizi menggunakan metode Dempster Shafer beserta cara penanganannya, menentukan status gizi berdasarkan berat badan menurut usia (BB/U), serta mengetahui berat badan ideal anak dan saran asupan makanannya. Sistem ini bekerja dengan melakukan perhitungan berdasarkan gejala-gejala penyakit yang dirasakan. Hasil pengujian menunjukan perbandingan antara hasil diagnosis yang dilakukan oleh pakar dan sistem, menghasilkan keluaran yang sama sehingga aplikasi ini dapat digunakan untuk mendiagnosis gangguan gizi serta mendapatkan informasi seputar gizi anak.
\end{abstract}

Kata Kunci: Sistem Pakar, Gangguan Gizi, Anak Prasekolah, Dempster Shafer.

\begin{abstract}
Nutrition is a determining factor in the quality of human resources in the future, besides that good nutritional status and balanced healthy food intake have an important role in determining one's health and intelligence. The age of preschool children is more at risk of experiencing nutritional disorders such as malnutrition and more nutrition can consequently cause disease. Lack of concern for children's nutrition and limited knowledge about various diseases due to nutritional disorders makes it difficult for parents to diagnose diseases that will attack their children. So in this study a tool was made in the form of an android-based expert system to diagnose diseases due to nutritional disorders using the Dempster Shafer method and how to handle it, determine nutritional status based on body weight according to age (BB/U), and find out the child's ideal body weight and intake advice the food. This system works by calculating based on the symptoms of the disease that is felt. The test results show a comparison between the results of diagnoses made by experts and systems, producing the same output so that this application can be used to diagnose nutritional disorders and obtain information about child nutrition.
\end{abstract}

Keywords: Expert System, Nutritional Disorders, Preschooler, Dempster Shafer. 


\section{Pendahuluan}

Kesehatan gizi mencerminkan derajat kesehatan bangsa, karena gizi merupakan faktor penentu kualitas Sumber Daya Manusia (SDM) di masa mendatang. Gizi seseorang dapat dilihat dari makanan yang dikonsumsi dan status gizi dengan cara menghitung indikator antropometri berdasarkan usia, jenis kelamin, berat badan dan tinggi badan (Nuryana, 2019). Status gizi adalah suatu ukuran mengenai kondisi tubuh seseorang dalam pemenuhan nutrisi dan penggunaan zat-zat gizi di dalam tubuh. Sedangkan asupan makanan yang memenuhi kandungan gizi yang seimbang merupakan kunci penting bagi pertumbuhan, karena membuat tubuh menjadi sehat dan tumbuh dengan baik (Pratiwi, Ziaurrahman, \& Qulub, 2018).

Usia anak prasekolah disebut sebagai periode golden age karena menjadi awal dari pertumbuhan fisik, mental dan kecerdasan. Masa ini akan berjalan baik bila didukung oleh gizi yang baik, terpenuhi dan seimbang. Gizi yang baik akan menjadi fondasi untuk status gizi, kesehatan jangka panjang, juga kekuatan dan perkembangan intelektualnya sehingga anak mampu mengembangkan potensinya secara maksimal (Davidson et al., 2018).

Namun anak usia prasekolah lebih beresiko mengalami gangguan gizi karena pada masa ini anak akan mengalami tumbuh kembang yang sangat pesat. Gangguan gizi dapat mengakibatkan kinerja anak dalam beraktifitas tidak optimal, terhambatnya proses tumbuh kembang, bahkan dapat menimbulkan penyakit (Setiawati, 2016). Kurangnya pemahaman dan kepedulian mengenai pemantauan status gizi anak yang dilakukan oleh orang tua menjadi salah satu penyebab adanya gangguan ini (Nyanyi, Wahyuni, \& AF, 2019).

Terbatasnya pengetahuan mengenai berbagai penyakit akibat gangguan gizi membuat orang tua kesulitan untuk mendiagnosis penyakit yang akan menyerang anak mereka. Oleh karena itu informasi yang cepat dan tepat dari seorang pakar tentang gejala dari gangguan gizi dan cara penanganannya sangat dibutuhkan oleh orang tua guna mencegah secara dini memburuknya kemungkinan yang akan terjadi (Wahyudi, Efendi, \& Setiawan, 2018). Munculnya teknologi kecerdasan buatan (Artificial Intelligence) dalam bidang kesehatan memacu pengembangan aplikasi sistem pakar untuk layanan kesehatan, salah satunya proses diagnosis penyakit (Yanto, Werdiningsih, \& Purwanti, 2017).

Sistem pakar (expert system) adalah sistem yang berusaha mengadopsi pola pikir manusia untuk selanjutnya di implementasikan ke dalam sebuah perangkat lunak, agar komputer dapat menyelesaikan masalah seperti yang biasa dilakukan oleh seorang pakar (Putra, Hafizh, \& Putra, 2018). Dengan sistem pakar proses konsultasi akan lebih mudah, karena pengetahuan para ahli gizi telah diadopsi ke dalam sistem ini (Pratiwi, Ziaurrahman, \& Qulub, 2018). Metode Dempster Shafer merupakan salah satu dari metode sistem pakar. Metode Dempster Shafer ini termasuk bagian dari cabang ilmu matematika dan biasa digunakan untuk menghitung probabilitas (Kanggeraldo, Sari, \& Zul, 2018). Metode ini menunjukkan suatu cara untuk memberikan bobot kenyakinan sesuai fakta yang dikumpulkan kemudian mengkombinasikan potongan informasi yang terpisah dan mengkalkulasikan kemungkinan dari suatu peristiwa. Logika ini digunakan untuk menghitung inputan data yang dilakukan oleh pasien guna mendapatkan persentase keakuratan hasil diagnosis (Hasibuan \& Batubara, 2019).

Dari penelitian yang dilakuan oleh Dina Hastari dan Fitri Bimantoro tahun 2018 yang berjudul Sistem Pakar untuk Mendiagnosis Gangguan Mental Anak Menggunakan Metode Dempster Shafer menghasilkan akurasi sebesar $95 \%$. Selain itu, penelitian dilakukan oleh Jansen Kanggeraldo, Rika Perdana Sari dan Muhammad Ihsan Zul tahun 2018 yang berjudul Sistem Pakar Untuk Mendiagnosis Penyakit Stroke Hemoragik dan Iskemik Menggunakan Metode Dempster Shafer menghasilkan akurasi sebesar $97 \%$. Dari kedua penelitian tersebut metode Dempster Shafer dapat menghasilkan data yang akurat.

Berdasarkan dari uraian di atas, dengan memanfaatkan teknologi smartphone berbasis android sebagai media dan alat bantu yang dapat digunakan kapan saja dan dimana saja oleh semua orang khususnya orang tua anak, maka penulis membuat "Aplikasi Sistem Pakar Diagnosis Gangguan Gizi Pada Anak Menggunakan Metode Dempster Shafer" yang diharapkan dapat membantu mengatasi permasalahan. 
Identifikasi Masalah

Berikut identifikasi permasalahan

pada penelitian ini:

1. Memberikan informasi berupa status gizi, berat badan ideal serta asupan makanan yang sesuai kebutuhan anak usia prasekolah.

2. Mengetahui cara mendiagnosis penyakit akibat gangguan gizi pada anak menggunakan metode Dempster Shafer berdasarkan gejalanya dan memberikan informasi penyebab dan solusi yang tepat.

3. Merancang dan membangun aplikasi sistem pakar berbasis android untuk memberikan informasi kesehatan gizi serta mendiagnosis gangguan gizi pada anak menggunakan metode Dempster Shafer.

\section{Metode Penelitian}

Metode penelitian digunakan dalam mengumpulkan data dan informasi.

\section{Metode Pengumpulan Data}

a. Observasi

Penulis melakukan observasi di Puskesmas Cileunyi dan TK PGRI Tunas Jelita guna mencari sampel anak dan untuk mendapatkan data.

b. Wawancara

Penulis melakukan wawancara dengan ahli gizi dan dokter umum di Puskesmas Cileunyi terkait data yang diperlukan untuk mengidentifikasi gangguan gizi serta penyakit akibat gangguan gizi pada anak.

c. Studi Pustaka

Penulis juga melakukan studi kepustakaan dengan mengumpulkan berbagai sumber pendukung melalui literatur dan referensi dari internet, jurnal, e-book, dan buku yang berkaitan dengan pembuatan skripsi.

\section{Metode Pengembangan Aplikasi}

Pada penelitian ini penulis menggunakan model waterfall. Adapun tahapan - tahapan metode waterfall adalah:

a. Analisis Kebutuhan

Pada tahap ini dilakukan sesuai dengan kebutuhan sistem yang dibangun untuk dapat melakukan diagnosis gangguan gizi dan penyakit akibat gangguan gizi pada anak. Kebutuhan yang dianalisa yaitu mengumpulkan data sebagai bahan untuk merancang aplikasi dengan cara wawancara dan survey langsung dengan pakar di Puskesmas Cileunyi.

b. Desain

Desain aplikasi yang dibangun dengan menggunakan Android Studio dan melakukan editing menggunakan Photoshop. Penulis menuangkan kebutuhan yang sudah dianalisa dalam bentuk desain antar muka dan desain struktur data.

c. Coding

Penulis menterjemahkan desain ke dalam coding dengan menggunakan bahasa pemograman Java.

d. Testing

Penulis melakukan pengujian aplikasi dengan pengujian Alpha menggunakan metode Blackbox dan pengujian sistem dengan pakar.

e. Implementasi

Penerapan dari hasil rancangan dengan membuat aplikasi berbasis android dan diimplementasikan di TK PGRI Tunas Jelita.

\section{Metode Dempster Shafer}

Metode dempster shafer merupakan salah satu metode dalam cabang ilmu matematika dan biasa digunakan untuk menghitung probabilitas. Metode ini digunakan untuk mengkombinasikan potongan informasi yang terpisah untuk mengkalkulasikan kemungkinan dari suatu peristiwa. Metode Dempster Shafer adalah metode penalaran non monotonis yang digunakan untuk mencari ketidakkonsistenan akibat adanya penambahan maupun pengurangan fakta baru yang akan merubah aturan yang ada, sehingga metode Dempster Shafer memungkinkan seseorang aman melakukan pekerjaan pakar, sekaligus dapat mengetahui persentase dari penyakit yang diderita (Kanggeraldo et al., 2018).

Teori ini dikembangkan oleh Arthur P. Dempster dan Glenn Shafer. Metode Dempster Shafer pertama kali diperkenalkan oleh Dempster, yang melakukan percobaan model ketidakpastian dengan range probabilitas sebagai probabilitas tunggal. Kemudian pada tahun 1976 Shafer mempublikasikan teori Dempster tersebut pada sebuah buku yang berjudul Mathematical Theory of Evident (Sari, Sembiring, \& Sinaga, 2017).

Secara umum teori Dempster Shafer ditulis dalam suatu interval seperti berikut (Orthega, Hidayat, \& Santoso, 2017): 
[Belief, Plausibility]

Belief (Bel) adalah ukuran kekuatan evidence dalam mendukung suatu himpunan proposisi. Jika bernilai 0 (nol) maka mengindikasikan bahwa tidak ada evidence, dan jika bernilai 1 menunjukkan adanya kepastian. Plausibility juga bernilai 0 sampai 1 , jika yakin akan X' maka dapat dikatakan Belief $\left(X^{\prime}\right)=1$ sehingga dari rumus nilai Pls $(X)=0$. Fungsi belief dapat diformulasikan sebagai berikut:

$$
\operatorname{Bel}(\mathrm{X})=\sum_{Y \subseteq X} m(Y)
$$

Dan Plausibility dinotasikan seperti berikut:

$$
\text { Pls }(\mathrm{X})=1-\operatorname{Bel}(\mathrm{X})=1-\sum_{Y \subseteq X} m(X)
$$

Keterangan:

Bel $(X)=$ Belief $(X)$

Pls $(X)=$ Plausibitily $(X)$

$\mathrm{m}(\mathrm{X})=$ mass function dari $(\mathrm{X})$

$\mathrm{m}(\mathrm{Y})=$ mass function dari $(\mathrm{Y})$

Teori Dempster Shafer menyatakan adanya frame of discrement yang dinotasikan dengan simbol $(\Theta)$. Frame of discrement merupakan pembicaraan dari sekumpulan hipotesis sehingga sering disebut dengan environment. Environment mengandung elemen-elemen yang menggambarkan kemungkinan sebagai jawaban, dan hanya ada satu yang akan sesuai dengan jawaban yang dibutuhkan. Kemungkinan ini dalam teori Dempster Shafer disebut dengan power set dan dinotasikan dengan $P(\Theta)$, setiap elemen dalam power set ini memiliki nilai interval antara 0 sampai 1 seperti rumus berikut:

$$
\sum_{X \subseteq P(\Theta)} m(X)=1 \approx \sum_{X \subseteq P(\theta)} m(X)=1
$$

Keterangan:

$\mathrm{P}(\Theta)=$ Power set

$\mathrm{m}(\mathrm{X})=$ Mass function $(\mathrm{X})$

Mass function (m) dalam teori Dempster shafer adalah tingkat kepercayaan dari suatu evidence (gejala) sehingga dinotasikan dengan $(m)$. Untuk itu perlu adanya probabilitas fungsi densitas (m). Apabila diketahui $X$ adalah subset dari $\theta$, dengan $\mathrm{m} 1$ sebagai fungsi densitasnya, dan $Y$ juga merupakan subset dari $\theta$ dengan $\mathrm{m} 2$ sebagai fungsi densitasnya, maka dapat dibentuk fungsi kombinasi $\mathrm{m} 1$ dan $\mathrm{m} 2$ sebagai $m 3$, ditunjukkan seperti berikut:

$$
m_{3}(Z)=\frac{\sum X \cap Y m_{1}(X) \cdot m_{2}(Y)}{1-\sum X \cap Y=\theta m_{1}(X) \cdot m_{2}(Y)}
$$

Keterangan:

$\mathrm{m} 1$ = Densitas untuk gejala pertama m2 = Densitas untuk gejala kedua $\mathrm{m} 3=$ Kombinasi dari kedua densitas diatas

$\theta=$ Sekumpulan hipotesis ( $X^{\prime}$ dan $Y^{\prime}$ )

$X$ dan $Y=$ Subset dari $Z$

$X^{\prime}$ dan $Y^{\prime}=$ Subset dari $\theta$

\section{Hasil dan Pembahasan}

3.1 Status Gizi

Klasifikasi untuk mengukur status gizi anak menurut Kementerian Kesehatan Republik Indonesia Tahun 2010, standar pertumbuhan yang menjadi acuan adalah

\begin{tabular}{|c|c|c|}
\hline \multicolumn{3}{|r|}{ Ambang } \\
\hline INDEKS & Status Gizi & $\begin{array}{c}\text { Ambang } \\
\text { Batas }\end{array}$ \\
\hline \multirow{4}{*}{$\begin{array}{c}\text { Berat Badan } \\
\text { menurut } \\
\text { Umur (BB/U) } \\
\text { Anak umur } \\
0-60 \text { bulan }\end{array}$} & Gizi Lebih & $>2 \mathrm{SD}$ \\
\hline & Gizi Baik & $\begin{array}{c}-2 \text { SD sd } \\
2 S D\end{array}$ \\
\hline & Gizi Kurang & $\begin{array}{c}-3 \text { SD sd } \\
<-2 \text { SD }\end{array}$ \\
\hline & Gizi Buruk & $<-3$ SD \\
\hline \multirow{4}{*}{$\begin{array}{c}\text { Tinggi Badan } \\
\text { menurut } \\
\text { Umur (TB/U) } \\
\text { Anak umur } \\
0-60 \text { bulan }\end{array}$} & Tinggi & $>2 \mathrm{SD}$ \\
\hline & Normal & $\begin{array}{c}-2 \text { SD sd } \\
2 S D\end{array}$ \\
\hline & Pendek & $\begin{array}{c}-3 \text { SD sd } \\
<-2 \text { SD }\end{array}$ \\
\hline & $\begin{array}{l}\text { Sangat } \\
\text { Pendek }\end{array}$ & $<-3 \mathrm{SD}$ \\
\hline \multirow{4}{*}{$\begin{array}{c}\text { Berat Badan } \\
\text { menurut } \\
\text { Tinggi Badan } \\
\text { (BB/TB) } \\
\text { Anak umur } \\
0-60 \text { bulan }\end{array}$} & Gemuk & $>2 \mathrm{SD}$ \\
\hline & Normal & $\begin{array}{c}-2 \mathrm{SD} \text { sd } \\
2 \mathrm{SD}\end{array}$ \\
\hline & Kurus & $\begin{array}{c}-3 \mathrm{SD} \text { sd } \\
<-2 \mathrm{SD}\end{array}$ \\
\hline & $\begin{array}{l}\text { Sangat } \\
\text { Kurus }\end{array}$ & $<-3 \mathrm{SD}$ \\
\hline \multirow{4}{*}{$\begin{array}{c}\text { Indeks } \\
\text { Massa } \\
\text { Tubuh } \\
\text { menurut } \\
\text { Umur } \\
\text { (IMT/U) } \\
\text { Anak umur } \\
0-60 \text { bulan }\end{array}$} & Gemuk & $>2 \mathrm{SD}$ \\
\hline & Normal & $\begin{array}{c}-2 S D \text { sd } \\
2 S D\end{array}$ \\
\hline & Kurus & $\begin{array}{l}-3 \text { SD sd } \\
<-2 \text { SD }\end{array}$ \\
\hline & $\begin{array}{l}\text { Sangat } \\
\text { Kurus }\end{array}$ & SD \\
\hline
\end{tabular}
standar WHO-NCHS seperti berikut:

Tabel 1. Klasifikasi Status Gizi Berdasarkan Kemenkes RI Tahun 2010

\subsection{Basis Pengetahuan}

Nilai kepercayaan merupakan nilai kemungkinan dari sebuah gejala terhadap suatu penyakit. Berdasarkan hasil wawancara dengan pakar, terdapat 8 penyakit dengan 33 gejala fisik yang dapat terlihat. Berikut daftar gejala dan penyakit gangguan gizi pada anak: 
Tabel 2. Data Penyakit Gangguan Gizi

\begin{tabular}{|c|c|}
\hline $\begin{array}{c}\text { Kode } \\
\text { Penyakit }\end{array}$ & Nama Penyakit \\
\hline P1 & TBC \\
\hline P2 & Campak \\
\hline P3 & Gondok \\
\hline P4 & Diare \\
\hline P5 & Anemia \\
\hline P6 & Sariawan \\
\hline P7 & Obesitas \\
\hline P8 & Diabetes \\
\hline
\end{tabular}

Tabel 3. Daftar Gejala Dengan Nilai

\begin{tabular}{|c|c|c|c|}
\hline $\begin{array}{l}\text { Kode } \\
\text { Gejala }\end{array}$ & Nama Gejala & $\begin{array}{l}\text { Nilai } \\
\text { Belief }\end{array}$ & $\begin{array}{l}\text { Nilai } \\
\text { Plausi } \\
\text { bility }\end{array}$ \\
\hline G01 & $\begin{array}{l}\text { Batuk } \\
\text { berlangsung } 2 \\
\text { minggu atau } \\
\text { lebih }\end{array}$ & 0.8 & 0.2 \\
\hline G02 & Batuk berdarah & 0.8 & 0.2 \\
\hline G03 & $\begin{array}{l}\text { Lemas dan } \\
\text { mudah lelah }\end{array}$ & 0.5 & 0.5 \\
\hline G04 & Demam & 0.3 & 0.7 \\
\hline G05 & $\begin{array}{l}\text { Berat badan } \\
\text { menurun }\end{array}$ & 0.5 & 0.5 \\
\hline G06 & Sesak napas & 0.6 & 0.4 \\
\hline G07 & Demam Tinggi & 0.8 & 0.2 \\
\hline G08 & $\begin{array}{l}\text { Ruam } \\
\text { kemerahan di } \\
\text { wajah }\end{array}$ & 0.6 & 0.4 \\
\hline G09 & $\begin{array}{l}\text { Bintik putih pada } \\
\text { area mulut }\end{array}$ & 0.6 & 0.4 \\
\hline G10 & $\begin{array}{l}\text { Mata merah dan } \\
\text { sensitif terhadap } \\
\text { cahaya }\end{array}$ & 0.6 & 0.4 \\
\hline G11 & $\begin{array}{l}\text { Nafsu makan } \\
\text { menurun }\end{array}$ & 0.5 & 0.5 \\
\hline G12 & Nyeri sendi & 0.2 & 0.8 \\
\hline G13 & Sakit kepala & 0.6 & 0.4 \\
\hline G14 & $\begin{array}{l}\text { Sakit saat } \\
\text { mengunyah } \\
\text { atau menelan } \\
\text { makanan }\end{array}$ & 0.8 & 0.2 \\
\hline G15 & $\begin{array}{l}\text { Mulut dan bibir } \\
\text { kering pecah- } \\
\text { pecah }\end{array}$ & 0.3 & 0.7 \\
\hline G16 & Sakit Perut & 0.8 & 0.2 \\
\hline G17 & $\begin{array}{l}\text { Feses yang } \\
\text { dihasilkan } \\
\text { banyak dan cair }\end{array}$ & 0.8 & 0.8 \\
\hline G18 & $\begin{array}{l}\text { Mual dan } \\
\text { muntah }\end{array}$ & 0.4 & 0.6 \\
\hline G19 & Dehidrasi & 0.6 & 0.4 \\
\hline G20 & $\begin{array}{l}\text { Kulit menjadi } \\
\text { lebih pucat } \\
\text { keabu-abuan }\end{array}$ & 0.4 & 0.6 \\
\hline
\end{tabular}

\begin{tabular}{|c|l|c|c|}
\hline G21 & $\begin{array}{l}\text { Rentan } \\
\text { mengalami } \\
\text { infeksi }\end{array}$ & 0.4 & 0.6 \\
\hline G22 & $\begin{array}{l}\text { Kulit atau area } \\
\text { mata yang } \\
\text { berwarna kuning }\end{array}$ & 0.4 & 0.6 \\
\hline G23 & $\begin{array}{l}\text { Detak jantung } \\
\text { cepat }\end{array}$ & 0.2 & 0.8 \\
\hline G24 & $\begin{array}{l}\text { Sering } \\
\text { berkeringat }\end{array}$ & 0.4 & 0.6 \\
\hline G25 & $\begin{array}{l}\text { Berat badan } \\
\text { berlebih }\end{array}$ & 0.8 & 0.2 \\
\hline G26 & $\begin{array}{l}\text { Tidur } \\
\text { mendengkur }\end{array}$ & 0.2 & 0.8 \\
\hline G27 & $\begin{array}{l}\text { Selalu merasa } \\
\text { kepanasan }\end{array}$ & 0.4 & 0.6 \\
\hline G28 & $\begin{array}{l}\text { Selalu merasa } \\
\text { haus }\end{array}$ & 0.8 & 0.2 \\
\hline G29 & $\begin{array}{l}\text { Sering buang air } \\
\text { kecil terutama } \\
\text { malam hari }\end{array}$ & 0.6 & 0.4 \\
\hline G30 & $\begin{array}{l}\text { Luka yang sulit } \\
\text { sembuh }\end{array}$ & 0.6 & 0.4 \\
\hline G31 & $\begin{array}{l}\text { Pembengkakan } \\
\text { gusi dan mudah } \\
\text { pendarahan }\end{array}$ & 0.6 & 0.4 \\
\hline
\end{tabular}

\subsection{Pohon Pakar}

Berikut ini pohon pakar dari sistem pakar diagnosis gangguan gizi pada anak:

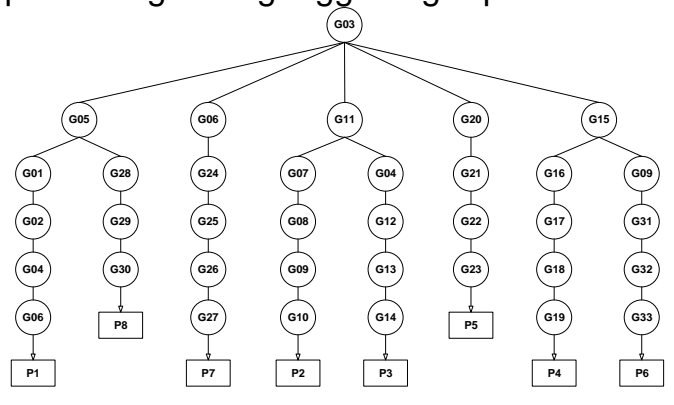

Gambar 1. Pohon Pakar

\subsection{Rancangan Algoritma}

Berikut ini flowchart dari algoritma sistem pakar diagnosis gangguan gizi pada anak dengan metode dempster shafer: 


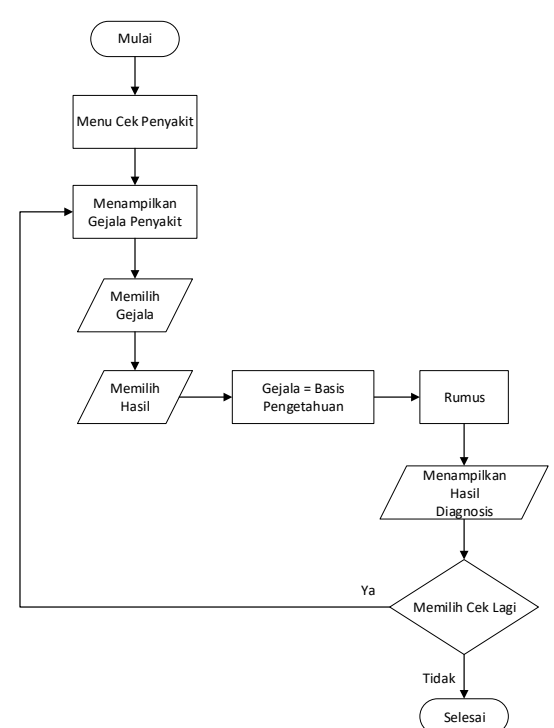

Gambar 2. Flowchart Algoritma

\subsection{Usecase Diagram}

Menggambarkan kebutuhan sistem dari sudut pandang user di aplikasi sistem pakar diagnosis gangguan gizi pada anak.

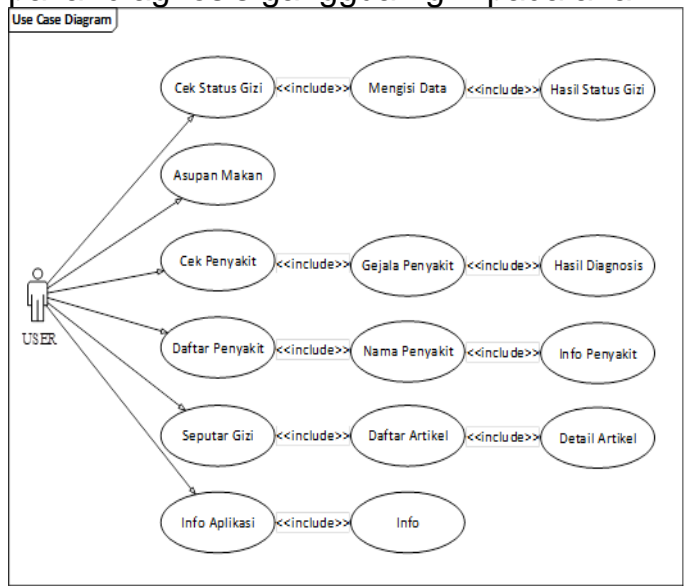

Gambar 3. Usecase Diagram

\subsection{Perhitungan Dempster Shafer} Tabel 4. Perhitungan DS

\begin{tabular}{|c|c|c|c|}
\hline $\begin{array}{l}\text { Kode } \\
\text { Gejala }\end{array}$ & $\begin{array}{l}\text { Nama Gejala } \\
\text { Penyakit TBC }\end{array}$ & $\begin{array}{l}\text { Nilai } \\
\text { Belief }\end{array}$ & $\begin{array}{l}\text { Nilai } \\
\text { Plau } \\
\text { sibili } \\
\text { ty }\end{array}$ \\
\hline G01 & $\begin{array}{l}\text { Batuk } \\
\text { berlangsung } 2 \\
\text { minggu atau } \\
\text { lebih }\end{array}$ & 0,8 & 0.2 \\
\hline G02 & $\begin{array}{l}\text { Batuk } \\
\text { berdahak atau } \\
\text { batuk } \\
\text { berdarah }\end{array}$ & 0,8 & 0.2 \\
\hline
\end{tabular}

\begin{tabular}{|c|l|c|c|}
\hline G03 & $\begin{array}{l}\text { Lemas dan } \\
\text { mudah lelah }\end{array}$ & 0,5 & 0.5 \\
\hline G04 & Demam & 0,3 & 0.7 \\
\hline G05 & $\begin{array}{l}\text { Berat badan } \\
\text { menurun }\end{array}$ & 0,5 & 0.5 \\
\hline G06 & Sesak napas & 0,65 & 0.35 \\
\hline
\end{tabular}

Gejala 01 (P1) dan Gejala 02 (P1,P2)

\begin{tabular}{|c|c|c|}
\hline & $\mathrm{M} 2\{\mathrm{P} 1, \mathrm{P} 2\} 0.8$ & $\mathrm{M} 2\{\theta\} 0.2$ \\
\hline $\mathrm{M} 1\{\mathrm{P} 1\}$ & $0.8 \times 0.8=0.64$ & $0.8 \times 0.2=0.16$ \\
0.8 & 0.8 .16 & $0.2 \times 0.2=0.04$ \\
\hline $\mathrm{M} 1\{\theta\} 0.2$ & $0.2 \times 0.8=0.16$ & 0.8 \\
\hline
\end{tabular}

$\mathrm{M} 3\{\mathrm{P} 1\}=0.64+0.16=\mathbf{0 . 8}$

$\mathrm{M} 3(\mathrm{P} 1, \mathrm{P} 2)=\mathbf{0 . 1 6}$

$\mathrm{M} 3\{\theta\}=0.04$

Gejala 03 (P1,P2,P3,P4,P5,P6,P7,P8)

\begin{tabular}{|c|c|c|}
\hline & $\begin{array}{c}\mathrm{M} 4\{\mathrm{P} 1-\mathrm{P} 8\} \\
0.5\end{array}$ & $\mathrm{M} 4\{\theta\} 0.5$ \\
\hline $\mathrm{M} 3\{\mathrm{P} 1\} 0.8$ & $\begin{array}{l}0.8 \times 0.5= \\
0.4\end{array}$ & $\begin{array}{l}0.8 \times 0.5= \\
0.4\end{array}$ \\
\hline $\begin{array}{l}\mathrm{M} 3(\mathrm{P} 1, \mathrm{P} 2)\{\theta\} \\
0.16\end{array}$ & $\begin{array}{l}0.16 \times 0.5= \\
0.08\end{array}$ & $\begin{array}{l}0.16 \times 0.5 \\
=0.08\end{array}$ \\
\hline $\mathrm{M} 3\{\theta\}$ & $\begin{array}{l}0.04 \times 0.5= \\
0.02\end{array}$ & $\begin{array}{l}0.04 \times 0.5 \\
=0.02\end{array}$ \\
\hline
\end{tabular}

M5 $\{\mathrm{P} 1\}=0.4+0.4=\mathbf{0 . 8}$

M5 $\{\mathrm{P} 1, \mathrm{P} 2\}=0.08+0.08=\mathbf{0 . 1 6}$

$\mathrm{M} 5\{\mathrm{P} 1-\mathrm{P} 8\}=\mathbf{0 . 0 2}$

$\mathrm{M} 5\{\theta\}=\mathbf{0 . 0 2}$

Gejala 04 (P1,P3,P5,P6)

\begin{tabular}{|c|c|c|}
\hline & $\begin{array}{c}M 6 \\
\{P 1, P 3, P 5, P 6\} \\
0.3\end{array}$ & $\mathrm{M} 6\{0\} 0.7$ \\
\hline M5 $\{\mathrm{P} 1\} 0.8$ & $\begin{array}{l}0.8 \times 0.3= \\
0.24\end{array}$ & $\begin{array}{l}0.8 \times 0.7= \\
0.56\end{array}$ \\
\hline $\begin{array}{c}\text { M5 }\{\mathrm{P} 1, \mathrm{P} 2\} \\
0.16\end{array}$ & $\begin{array}{l}0.16 \times 0.3= \\
0.0048\end{array}$ & $\begin{array}{l}0.16 \times 0.7= \\
0.112\end{array}$ \\
\hline $\begin{array}{c}\text { M5 }\{\text { P1-P8 }\} \\
0.02\end{array}$ & $\begin{array}{l}0.02 \times 0.3= \\
0.006\end{array}$ & $\begin{array}{l}0.02 \times 0.7= \\
0.014\end{array}$ \\
\hline M5 $\{\theta\} 0.1$ & $\begin{array}{l}0.02 \times 0.3= \\
0.006\end{array}$ & $\begin{array}{l}0.02 \times 0.7= \\
0.014\end{array}$ \\
\hline
\end{tabular}

$\mathrm{M} 7\{\mathrm{P} 1\}=0.24+0.048+0.56=\mathbf{0 . 8 4 8}$

$\mathrm{M} 7\{\mathrm{P} 1, \mathrm{P} 2\}=\mathbf{0 . 1 1 2}$

$M 7\{P 1-P 8\}=\mathbf{0 . 0 1 4}$

$M 7\{P 1, P 3, P 5, P 6\}=0.006+0.006=0.012$ $\mathrm{M} 7\{\theta\}=\mathbf{0 . 0 1 4}$

Gejala 05 (P1,P8)

\begin{tabular}{|c|c|c|}
\hline & $\begin{array}{c}\mathrm{M} 8\{\mathrm{P} 1, \mathrm{P} 8\} \\
0.5\end{array}$ & M8 \{0\} 0.5 \\
\hline $\begin{array}{c}\text { M7 }\{\mathrm{P} 1\} \\
0.848 \\
\end{array}$ & $\begin{array}{l}0.848 \times 0.5= \\
0.424\end{array}$ & 0.4 \\
\hline $\begin{array}{c}\mathrm{M} 7 \\
\{\mathrm{P} 1, \mathrm{P} 3, \mathrm{P} 5, \mathrm{P} 6\} \\
0.012\end{array}$ & $\begin{array}{c}0.012 \times 0.5= \\
0.006\end{array}$ & $\begin{array}{l}0.012 \times 0.5 \\
=0.006\end{array}$ \\
\hline $\begin{array}{c}\mathrm{M} 7\{\mathrm{P} 1, \mathrm{P} 2\} \\
0.112\end{array}$ & $\begin{array}{c}0.112 \times 0.5= \\
0.056\end{array}$ & $\begin{array}{c}0.112 \times 0.5= \\
0.056\end{array}$ \\
\hline $\begin{array}{c}\mathrm{M} 7\{\mathrm{P} 1-\mathrm{P} 8\} \\
0.014 \\
\end{array}$ & $\begin{array}{c}0.014 \times 0.5= \\
0.007\end{array}$ & $\begin{array}{c}0.014 \times 0.5= \\
0.007\end{array}$ \\
\hline $\mathrm{M} 7\{\theta\} 0.014$ & $\begin{array}{c}0.014 \times 0.5= \\
0.007\end{array}$ & $\begin{array}{l}0.014 \times 0.5= \\
0.007\end{array}$ \\
\hline
\end{tabular}

M9 $\{\mathrm{P} 1\}=0.424+0.006+0.056+0.424=\mathbf{0 . 9 1}$ $\mathrm{M} 9\{\mathrm{P} 1, \mathrm{P} 8\}=0.007+0.007=\mathbf{0 . 0 1 4}$ 
$\mathrm{M} 9\{\mathrm{P} 1, \mathrm{P} 3, \mathrm{P} 5, \mathrm{P} 6\} \mathbf{=} \mathbf{0 . 0 0 6}$

$\mathrm{M} 9\{\mathrm{P} 1, \mathrm{P} 2\}=\mathbf{0 . 0 5 6}$

$\mathrm{M} 9\{\mathrm{P} 1-\mathrm{P} 8\}=\mathbf{0 . 0 0 7}$

M9 $\{\theta\}=\mathbf{0 . 0 0 7}$

Gejala 06 (P1,P5,P6,P7)

\begin{tabular}{|c|c|c|}
\hline & $\begin{array}{c}\mathrm{M} 10\{\mathrm{P} 1\} \\
0.65\end{array}$ & $\begin{array}{c}\text { M10 }\{0\} \\
0.35\end{array}$ \\
\hline$M 9\{P 1\} 0.91$ & $\begin{array}{c}\{P 1\} \\
0.392192\end{array}$ & $\begin{array}{c}\{P 1\} 0.91 \times \\
0.35= \\
0.3185\end{array}$ \\
\hline $\begin{array}{c}\mathrm{M} 9\{\mathrm{P} 1, \mathrm{P} 8\} \\
0.014\end{array}$ & $\begin{array}{c}0.014 \times 0.65 \\
=0.0091\end{array}$ & $\begin{array}{l}0.014 x \\
0.35= \\
0.0049\end{array}$ \\
\hline $\begin{array}{c}\mathrm{M} 9 \\
\{\mathrm{P} 1, \mathrm{P} 3, \mathrm{P} 5, \mathrm{P} 6\} \\
0.006 \\
\end{array}$ & $\begin{array}{c}0.006 \times 0.65 \\
=0.0039\end{array}$ & $\begin{array}{l}0.006 \times \\
0.35= \\
0.0021\end{array}$ \\
\hline $\begin{array}{c}M 9\{P 1, P 2\} \\
0.056\end{array}$ & $\begin{array}{c}0.056 \times 0.65 \\
=0.0364\end{array}$ & $\begin{array}{l}0.056 x \\
0.35= \\
0.0196\end{array}$ \\
\hline $\begin{array}{c}\text { M9 }\{\text { P1-P8 }\} \\
0.007\end{array}$ & $\begin{array}{c}0.007 \times 0.65 \\
=0.00455\end{array}$ & $\begin{array}{c}0.007 x \\
0.35= \\
0.00245\end{array}$ \\
\hline M9 $\{\theta\} 0.007$ & $\begin{array}{c}0.007 \times 0.65 \\
=0.00455\end{array}$ & $\begin{array}{c}\{\theta\} 0.007 \times \\
0.35= \\
0.00245 \\
\end{array}$ \\
\hline
\end{tabular}

$\mathrm{M} 11\{\mathrm{P} 1\}=0.5915+0.0091+0.0364+$

$0.3185=0.9555$

$\mathrm{M} 11\{\mathrm{P} 1, \mathrm{P} 5, \mathrm{P} 6, \mathrm{P} 7\}=0.00455+0.00455=$ 0.0091

$\mathrm{M} 11\{\mathrm{P} 1, \mathrm{P} 5, \mathrm{P} 6\}=\mathbf{0 . 0 0 3 9}$

$\mathrm{M} 11\{\mathrm{P} 1, \mathrm{P} 8\}=\mathbf{0 . 0 0 4 9}$

$\mathrm{M} 11\{\mathrm{P} 1, \mathrm{P} 3, \mathrm{P} 5, \mathrm{P} 6\} \mathbf{=} \mathbf{0 . 0 0 2 1}$

$\mathrm{M} 11\{\mathrm{P} 1, \mathrm{P} 2\}=\mathbf{0 . 0 1 9 6}$

$\mathrm{M} 11\{\mathrm{P} 1-\mathrm{P} 8\}=\mathbf{0 . 0 0 2 4 5}$

$\mathrm{M} 11\{\theta\}=\mathbf{0 . 0 0 2 4 5}$

Diketahui dari perhitungan di atas nilai densitas yang paling tinggi dari keenam nilai densitas yang dihasilkan yaitu M11 $\{\mathrm{P} 1\}=$ 0.9555 . Jadi presentase nilai kemungkinan penyakit TBC sebesar 95\%.

\subsection{Implementasi}

\section{A. Tampilan Splash}

User akan melihat tampilan splash screen terlebih dahulu yang berupa gambar logo dan nama dari aplikasi.

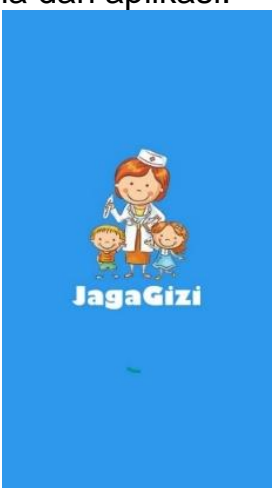

Gambar 4. Tampilan Splash

\section{B. Tampilan Menu Utama}

User akan melihat tampilan menu utama yang berisi 6 icon menu yaitu menu cek status gizi, menu asupan makan, menu cek penyakit, menu daftar penyakit, menu seputar gizi dan menu info aplikasi.

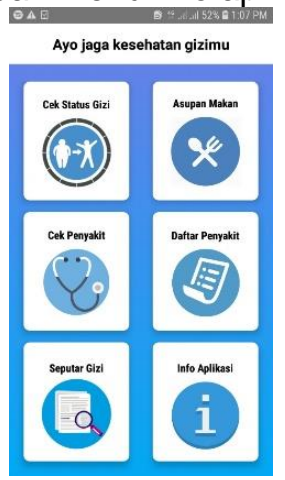

\section{Gambar 5. Tampilan Menu Utama}

\section{Tampilan Menu Cek Status Gizi}

User harus menginput data yang berupa nama, jenis kelamin, usia, berat badan dan tinggi badan anak untuk mengetahui hasil status gizi..

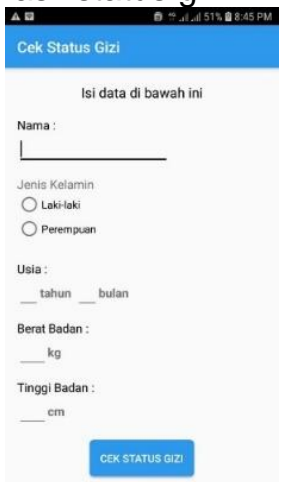

\section{Gambar 6. Tampilan Menu Status Gizi}

\section{Tampilan Hasil Status Gizi}

User akan melihat tampilan hasil status gizi dan berat badan ideal anak serta tombol cek lagi dan tombol selesai untuk keluar dari menu cek status gizi.

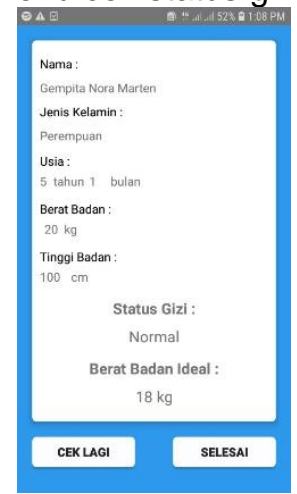

Gambar 7. Tampilan Hasil Status Gizi 


\section{E. Tampilan Menu Asupan Makan}

User akan melihat informasi berupa tabel asupan makan anak dalam sehari berdasarkan usia dan kebutuhannya.

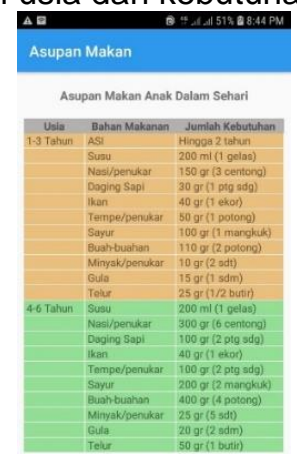

Gambar 8. Tampilan Menu Asupan Makan

\section{F. Tampilan Menu Cek Penyakit}

User akan melihat gejala-gejala penyakit yang berupa cekbox untuk dipilih.

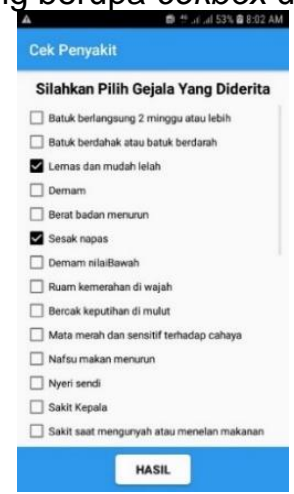

\section{Gambar 9. Tampilan Menu Cek Penyakit}

G. Tampilan Hasil Diagnosis Penyakit User akan melihat tampilan hasil diagnosis penyakit beserta solusi penanganannya serta tombol cek lagi dan selesai untuk keluar dari menu cek penyakit.

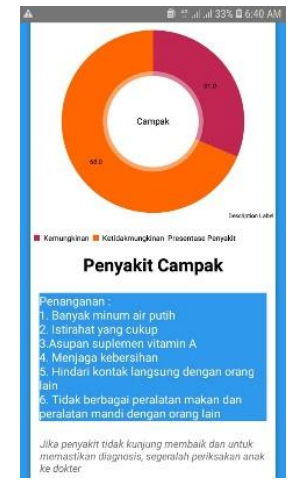

\section{Gambar 10. Tampilan Hasil Diagnosis}

\section{H. Tampilan Menu Daftar Penyakit}

Pada menu daftar penyakit, user akan melihat tampilan berupa 8 list penyakit yang dapat dipilih untuk mengetahui informasi penyakit tersebut.

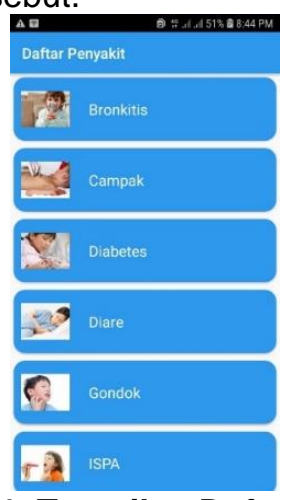

Gambar 11. Tampilan Daftar Penyakit

\section{Tampilan Info Penyakit}

User akan melihat tampilan berupa gambar dan informasi dari penyakit yang dipilih.

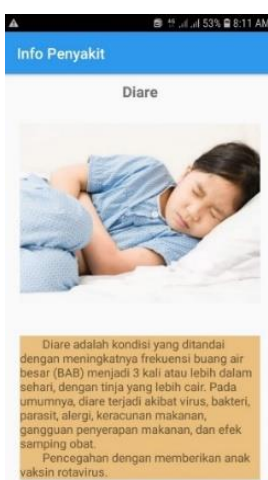

\section{Gambar 12. Tampilan Info Penyakit}

\section{J. Tampilan Menu Seputar Gizi}

User akan melihat tampilan daftar artikel yang bisa dipilih untuk mengetahui informasi dari artikel tersebut.

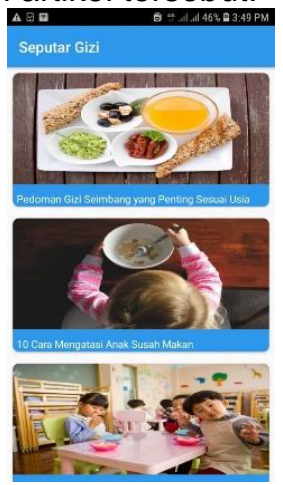

\section{Gambar 13. Tampilan Menu Seputar Gizi}

\section{K. Tampilan Detail Artikel}

User akan dialihkan ke sebuah situs website untuk melihat tampilan detail artikel. 


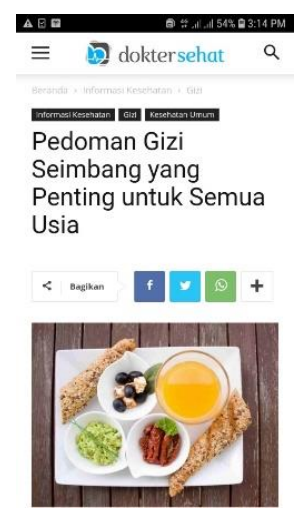

Gambar 14. Tampilan Detail Artikel

\section{Tampilan Menu Info Aplikasi}

User akan melihat tampilan yang berupa informasi tentang aplikasi dan penjelasan dari setiap menu yang ada di aplikasi. User juga dapat menekan button info aplikasi untuk melihat informasi dari pembuat aplikasi.

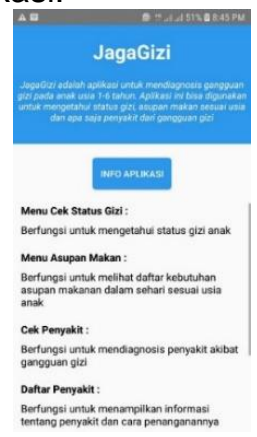

Gambar 15. Tampilan Menu Info Aplikasi

M. Tampilan Info Aplikasi

User akan melihat tampilan berupa informasi biodata dari pembuat aplikasi.

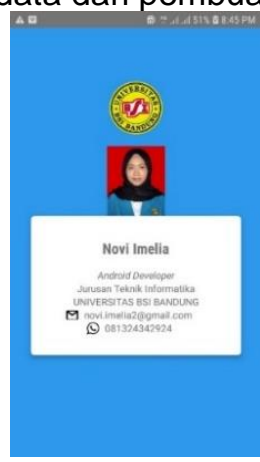

\section{Gambar 16. Tampilan Info Aplikasi}

\section{N. Tampilan Keluar}

User akan melihat tampilan kotak peringatan ya dan tidak yang dapat dipilih untuk keluar dari aplikasi.

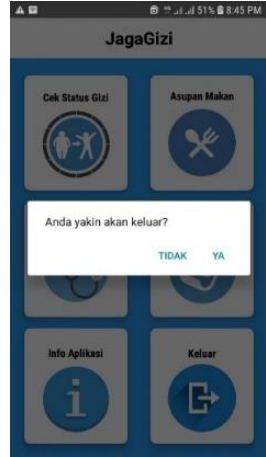

Gambar 17. Tampilan Menu Keluar

3.8 Hasil

Tabel 5. Hasil Pengujian Sistem Dengan Pakar

\begin{tabular}{|c|c|c|c|}
\hline Gejala & $\begin{array}{c}\text { Hasil } \\
\text { Sistem }\end{array}$ & $\begin{array}{l}\text { Hasil } \\
\text { Pakar }\end{array}$ & Ket \\
\hline $\begin{array}{l}\text { Batuk } \\
\text { berlang- } \\
\text { sung } 2 \\
\text { minggu } \\
\text { atau lebih }\end{array}$ & \multirow{6}{*}{$\begin{array}{c}\mathrm{T} \\
\mathrm{B} \\
\mathrm{C} \\
95 \%\end{array}$} & \multirow{6}{*}{$\begin{array}{l}\mathrm{T} \\
\mathrm{B} \\
\mathrm{C}\end{array}$} & Valid \\
\hline $\begin{array}{l}\text { Batuk } \\
\text { berdahak } \\
\text { atau batuk } \\
\text { berdarah }\end{array}$ & & & Valid \\
\hline $\begin{array}{l}\text { Lemas dan } \\
\text { mudah } \\
\text { lelah }\end{array}$ & & & Valid \\
\hline Demam & & & Valid \\
\hline $\begin{array}{l}\text { Berat } \\
\text { badan } \\
\text { menurun }\end{array}$ & & & Valid \\
\hline $\begin{array}{l}\text { Sesak } \\
\text { napas }\end{array}$ & & & Valid \\
\hline $\begin{array}{l}\text { Lemas dan } \\
\text { mudah } \\
\text { lelah }\end{array}$ & \multirow{6}{*}{$\begin{array}{c}C \\
A \\
M \\
P \\
A \\
K \\
98 \%\end{array}$} & \multirow{6}{*}{$\begin{array}{l}C \\
A \\
M \\
P \\
A \\
K\end{array}$} & Valid \\
\hline $\begin{array}{l}\text { Demam } \\
\text { Tinggi }\end{array}$ & & & Valid \\
\hline $\begin{array}{l}\text { Ruam } \\
\text { kemerahan } \\
\text { di wajah }\end{array}$ & & & Valid \\
\hline $\begin{array}{l}\text { Bercak } \\
\text { keputihan } \\
\text { di mulut }\end{array}$ & & & Valid \\
\hline $\begin{array}{l}\text { Mata } \\
\text { merah dan } \\
\text { sensitif } \\
\text { terhadap } \\
\text { cahaya }\end{array}$ & & & Valid \\
\hline $\begin{array}{l}\text { Nafsu } \\
\text { makan } \\
\text { menurun }\end{array}$ & & & Valid \\
\hline
\end{tabular}




\begin{tabular}{|c|c|c|c|}
\hline $\begin{array}{l}\text { Lemas dan } \\
\text { mudah } \\
\text { lelah }\end{array}$ & \multirow{6}{*}{$\begin{array}{c}G \\
O \\
N \\
D \\
O \\
K \\
89 \%\end{array}$} & \multirow{6}{*}{$\begin{array}{c}G \\
O \\
N \\
D \\
O \\
K\end{array}$} & Valid \\
\hline Demam & & & Valid \\
\hline $\begin{array}{l}\text { Nafsu } \\
\text { makan } \\
\text { menurun }\end{array}$ & & & Valid \\
\hline Nyeri sendi & & & Valid \\
\hline $\begin{array}{l}\text { Sakit } \\
\text { kepala }\end{array}$ & & & Valid \\
\hline $\begin{array}{l}\text { Sakit saat } \\
\text { mengu- } \\
\text { nyah atau } \\
\text { menelan } \\
\text { makanan }\end{array}$ & & & Valid \\
\hline $\begin{array}{l}\text { Lemas dan } \\
\text { mudah } \\
\text { lelah }\end{array}$ & & & Valid \\
\hline $\begin{array}{l}\text { Mulut dan } \\
\text { bibir kering }\end{array}$ & $\begin{array}{l}D \\
1\end{array}$ & D & Valid \\
\hline Sakit Perut & $A$ & 1 & Valid \\
\hline $\begin{array}{l}\text { Feses } \\
\text { yang } \\
\text { dihasilkan } \\
\text { banyak } \\
\text { dan cair }\end{array}$ & $\begin{array}{c}\mathrm{A} \\
\mathrm{R} \\
\mathrm{E} \\
99 \%\end{array}$ & $\begin{array}{l}A \\
R \\
E\end{array}$ & Valid \\
\hline $\begin{array}{l}\text { Mual dan } \\
\text { muntah }\end{array}$ & & & Valid \\
\hline Dehidrasi & & & Valid \\
\hline $\begin{array}{l}\text { Lemas dan } \\
\text { mudah } \\
\text { lelah }\end{array}$ & & & Valid \\
\hline $\begin{array}{l}\text { Kulit } \\
\text { menjadi } \\
\text { lebih pucat } \\
\text { keabu- } \\
\text { abuan }\end{array}$ & $\begin{array}{l}A \\
N \\
E\end{array}$ & $\mathrm{~A}$ & Valid \\
\hline $\begin{array}{l}\text { Rentan } \\
\text { mengalami } \\
\text { infeksi }\end{array}$ & M & $\begin{array}{l}E \\
M\end{array}$ & Valid \\
\hline $\begin{array}{l}\text { Kulit atau } \\
\text { area mata } \\
\text { yang } \\
\text { berwarna } \\
\text { kuning }\end{array}$ & $\begin{array}{c}\mathrm{A} \\
92 \%\end{array}$ & $\begin{array}{l}\mathrm{I} \\
\mathrm{A}\end{array}$ & Valid \\
\hline $\begin{array}{l}\text { Detak } \\
\text { jantung } \\
\text { cepat }\end{array}$ & & & Valid \\
\hline $\begin{array}{l}\text { Lemas dan } \\
\text { mudah } \\
\text { lelah }\end{array}$ & $\begin{array}{l}S \\
A\end{array}$ & $\begin{array}{l}\mathrm{S} \\
\mathrm{A}\end{array}$ & Valid \\
\hline $\begin{array}{l}\text { Bintik putih } \\
\text { pada area } \\
\text { mulut }\end{array}$ & $\begin{array}{c}\mathrm{R} \\
\mathrm{I}\end{array}$ & $\begin{array}{l}\mathrm{R} \\
\mathrm{I}\end{array}$ & Valid \\
\hline $\begin{array}{l}\text { Pembengk } \\
\text { akan gusi } \\
\text { dan mudah }\end{array}$ & $\begin{array}{l}A \\
W\end{array}$ & $\begin{array}{l}A \\
W\end{array}$ & Valid \\
\hline
\end{tabular}

\begin{tabular}{|c|c|c|c|}
\hline $\begin{array}{l}\text { pendarah- } \\
\text { an }\end{array}$ & & A & \\
\hline $\begin{array}{l}\text { Kesulitan } \\
\text { makan } \\
\text { atau } \\
\text { minum }\end{array}$ & $\begin{array}{c}N \\
92 \%\end{array}$ & & Valid \\
\hline $\begin{array}{l}\text { Mulut dan } \\
\text { bibir kering } \\
\text { pecah- } \\
\text { pecah }\end{array}$ & & & Valid \\
\hline $\begin{array}{l}\text { Warna } \\
\text { bibir pucat }\end{array}$ & & & Valid \\
\hline $\begin{array}{l}\text { Lemas dan } \\
\text { mudah } \\
\text { lelah }\end{array}$ & 0 & 0 & Valid \\
\hline $\begin{array}{l}\text { Sesak } \\
\text { Napas }\end{array}$ & B & B & Valid \\
\hline $\begin{array}{l}\text { Sering } \\
\text { berkeringat }\end{array}$ & S & E & Valid \\
\hline $\begin{array}{l}\text { Berat } \\
\text { badan } \\
\text { berlebih }\end{array}$ & $\begin{array}{l}\mathrm{I} \\
\mathrm{T}\end{array}$ & $\begin{array}{l}S \\
1\end{array}$ & Valid \\
\hline $\begin{array}{l}\text { Tidur } \\
\text { mendeng- } \\
\text { kur }\end{array}$ & $\begin{array}{l}A \\
S\end{array}$ & A & Valid \\
\hline $\begin{array}{l}\text { Selalu } \\
\text { merasa } \\
\text { kepanasan }\end{array}$ & $94 \%$ & $S$ & Valid \\
\hline $\begin{array}{l}\text { Lemas dan } \\
\text { mudah } \\
\text { lelah }\end{array}$ & & & Valid \\
\hline $\begin{array}{l}\text { Berat } \\
\text { badan } \\
\text { menurun }\end{array}$ & $\begin{array}{l}D \\
\text { I }\end{array}$ & D & Valid \\
\hline $\begin{array}{l}\text { Selalu } \\
\text { merasa } \\
\text { haus }\end{array}$ & $\begin{array}{l}\text { A } \\
B\end{array}$ & A & Valid \\
\hline $\begin{array}{l}\text { Sering } \\
\text { buang air } \\
\text { kecil } \\
\text { terutama } \\
\text { malam hari }\end{array}$ & $\begin{array}{l}\mathrm{E} \\
\mathrm{T} \\
\mathrm{E}\end{array}$ & $\begin{array}{l}\mathrm{E} \\
\mathrm{T} \\
\mathrm{E}\end{array}$ & Valid \\
\hline $\begin{array}{l}\text { Sering } \\
\text { merasa } \\
\text { lapar }\end{array}$ & $\begin{array}{c}S \\
98 \%\end{array}$ & $S$ & Valid \\
\hline $\begin{array}{l}\text { Luka yang } \\
\text { sulit } \\
\text { sembuh }\end{array}$ & & & Valid \\
\hline
\end{tabular}

Kesesuaian pengujian antara pakar dan sistem pakar diagnosis gangguan gizi pada anak menggunakan metode dempster shafer menghasilkan keluaran yang sama sehingga aplikasi ini layak untuk digunakan. 


\section{Kesimpulan}

Berdasarkan hasil analisis dan pengujian terhadap aplikasi sistem pakar diagnosis gangguan gizi pada anak menggunakan metode dempster shafer, maka dapat disimpulkan bahwa:

1. Sistem pakar ini dapat membantu masyarakat terutama orang tua anak dalam mendapatkan informasi seputar gizi, status gizi, berat badan ideal, asupan makanan sesuai kebutuhan anak dan mendiagnosis gangguan gizi pada anak.

2. Penerapan metode dempster shafer merupakan metode yang sesuai dalam aplikasi sistem pakar ini sehingga dapat menghasilkan penyakit akibat gangguan gizi berdasarkan gejala disertai solusi penanganannya.

3. Kesesuaian pengujian dengan melakukan perbandingan antara pakar dan aplikasi sistem pakar diagnosis gangguan gizi pada anak menghasilkan keluaran yang sama.

4. Penerapan sistem pakar untuk mendiagnosis gangguan gizi serta memberikan informasi seputar gizi anak ini lebih mudah diakses karena

Saran berbasis android.

disarankan:

Untuk pengembangan selanjutnya

1. Aplikasi sistem pakar ini dapat dikembangkan lebih lanjut dengan pembaharuan data seperti memperbanyak list pada asupan makan dan tambahan data penyakit.

2. Untuk mengklasifikasikan status gizi pada anak dapat ditambahkan indikator seperti Tinggi Badan menurut Umur (TB/U), Berat Badan menurut Umur (BB/TB) dan menurut Indeks Massa Tubuh (IMT).

3. Untuk perbandingan aplikasi sistem pakar gangguan gizi pada anak ini dapat dikembangkan lagi menggunakan metode yang berbeda seperti metode fuzzy logic, fuzzy tsukamoto atau fuzzy mamdani.

4. Untuk pengembangan selanjutnya aplikasi sistem pakar ini diharapkan dapat diperluas untuk semua usia agar tidak terbatas hanya pada usia anak prasekolah.

5. Aplikasi sistem pakar ini dapat dikembangkan dengan menambahkan fitur seperti mengelola data admin dan forum chating pakar sehingga user dapat berkonsultasi langsung dengan pakar.

\section{Referensi}

Davidson, S. M., Dwiriani, C. M., Khomsan, A., Masyarakat, D. G., Manusia, F. E., \& Bogor, I. P. (2018). Densitas Gizi dan Morbiditas serta Hubungannya dengan Status Gizi Anak Usia Prasekolah Pedesaan Nutrient Density and Morbidity and its Relationship with Nutritional Status of Preschool Children in Rural Areas. 14(3), 251259.

Fitri, L. K. S., Tjandrarini, A. ., \& Amelia, T. (2015). Rancang Bangun Aplikasi Penentuan Bahan Makanan Berdasarkan Status Gizi Pada Pasien Rawat Jalan. Jsika, 4(1), 24-30.

Hasibuan, P. S., \& Batubara, M. I. (2019). Penerapan Metode Dempster Shafer Dalam Mendiagnosa Penyakit Faringitis. 3(1), 59-64. https://doi.org/10.30865/mib.v3i1.1061

Hastari, D. F. B. (2018). Sistem Pakar untuk Mendiagnosis Gangguan Mental Anak Menggunakan Metode. 2(2).

Kanggeraldo, J., Sari, R. P., \& Zul, M. I. (2018). Sistem Pakar Untuk Mendiagnosis Penyakit Stroke Hemoragik dan Iskemik Menggunakan Metode Dempster Shafer. 2(2), 498505.

M. Ihsan Zul, Rika, J. K. (2018). Sistem Pakar Untuk Mendiagnosis Penyakit Stroke Hemoragik dan Iskemik Menggunakan Metode Dempster Shafer. 2(2), 498-505.

Nuryana, A. (2019). Sistem Pakar Nutrition Planuntuk Orang Dewasa Dengan Metode Forward Chaining Berbasis Website. Jurnal Teknologi Informasi Dan Terapan, 4(1), 25-32. https://doi.org/10.25047/jtit.v4i1.17

Nyanyi, M. F. A., Wahyuni, T. D., \& AF, S. M. (2019). Pola asuh ibu yang mempengaruhi perilaku sulit makan pada anak prasekolah (4-6 tahun). Nursing News, 4.

Orthega, S., Hidayat, N., \& Santoso, E. (2017). Implementasi Metode Dempster-Shafer untuk Mendiagnosa Penyakit Tanaman Padi. 1(10).

Pratiwi, M. E., Ziaurrahman, M., \& Qulub, M. (2018). SISTEM PAKAR REKOMENDASI KEBUTUHAN GIZI. 37-42. 
Putra, T. A., Hafizh, M., \& Putra. (2018). Implementasi Metode Dempster Shafer pada Sistem Pakar Diagnosis Penyakit Ginjal Berbasis Web dengan Menggunakan PHP dan MySQL. 7(1), 143-152.

Sari, N., Sembiring, B., \& Sinaga, M. D. (2017). Penerapan Metode Dempster Shafer Untuk Mendiagnosa Penyakit Dari Akibat Bakteri Treponema Pallidum. 9(3), 180-189.

Setiawati. (2016). Hubungan Kebiasaan Makan Dengan Terjadinya Gangguan Makan Pada Anak Usia Pra Sekolah Di Yayasan Pendidikan Islam Riyadol Mahirin Cimahi. Jurnal Kesehatan Kartika, 11(3), 43-47.

Wahyudi, A., Efendi, R., \& Setiawan, Y. (2018). DIAGNOSAPENYAKIT PADA BALITA MENGGUNAKAN METODE DEMPSTER-SHAFER. 6(1), 80-87.

Yanto, B. F., Werdiningsih, I., \& Purwanti, E. (2017). Aplikasi Sistem Pakar Diagnosa Penyakit Pada Anak Bawah Lima Tahun Menggunakan Metode Forward Chaining. Journal of Information Systems Engineering and Business Intelligence, 3(1), 61. https://doi.org/10.20473/jisebi.3.1.6167 